\title{
Plant population and row spacing on biomass sorghum yield performance
}

\section{Espaçamento entrelinhas e população de plantas no desempenho produtivo do sorgo biomassa}

\author{
Andre May ${ }^{I}$ Vander Fillipe de Souza ${ }^{I I}$ \\ Geraldo de Amaral Gravina ${ }^{\text {III }}$ Pedro Gonçalves Fernandes $^{\text {IV }}$
}

\section{ABSTRACT}

Biomass sorghum is one of the most promising crops for the production of electricity through the burning in high-pressure boilers, due to its high calorific value, high yield, seed propagation, short cycle, and to the possibility of full mechanization of its agricultural processes. However, there is still a lack of information about its cultural practices. To this end, this research aimed to evaluate the influence of row spacing and plant population on the yield performance of biomass sorghum. The experimental design was a randomized block, in factorial scheme of $4 \times 4$, with four row spacings $(0.5,0.7,0.9$ and $1.1 \mathrm{~m})$, and four plant populations (80,000; 100,000; 120,000 and 140,000 plants $\left.h a^{-1}\right)$, with three replications. The characteristics evaluated were: plant height, stem diameter, number of leaves, number of tillers per plant, fresh weight per plant and biomass. Total biomass yield was greatly influenced by the row spacing, showing a sharp reduction when row spacing increased, in the two years of study, changing from 180.27 to $114.42 \mathrm{t} \mathrm{ha^{-1 }}$ in the 2012/13 crop year, and from 146.50 to $102.56 \mathrm{tha}^{-1}$ in the 2013/14 crop year, for 0.5 and $1.1 \mathrm{~m}$ between rows, respectively. The lowest yields observed in the second year of the study were due to unfavorable weather conditions in the period.

Key words: lignocellulosic sorghum, plant spacing, seeding density, bio-energy, cultural management.

RESUMO

Osorgo biomassaé uma das culturas mais promissoras para a produção de energia elétrica, através da queima da planta inteira em caldeiras de alta pressão, devido ao seu alto poder calorifico, alta produtividade, propagação por sementes, ciclo curto e por possibilitar mecanização completa de seus processos agrícolas. Contudo, ainda há uma carência de informações acerca do seu manejo cultural. Para tanto, esta pesquisa objetivou avaliar a influência do espaçamento entrelinhas e da população de plantas no desempenho produtivo do sorgo biomassa. Os experimentos foram instalados em Sete Lagoas/MG, na Embrapa Milho e Sorgo, durante duas safras consecutivas. $O$ delineamento experimental utilizado foi em blocos ao acaso, em esquema fatorial $4 \times 4$, sendo 4 espaçamentos entrelinhas $(0,5 ; 0,7 ; 0,9$ e 1,1m) e 4 populações de plantas (80.000; 100.000; 120.000 e 140.000 plantas $\left.h^{-1}\right) e$ utilizadas três repetições. As características avaliadas foram: altura da planta, diâmetro do colmo, número de folhas, número de perfilhos por planta, massa fresca por planta e biomassa total por área cultivada. A produtividade de biomassa total foi influenciada pelo espaçamento entrelinhas, apresentando uma forte redução com o aumento do espaçamento entrelinhas para os dois anos de estudos, passando de 180,27 para 114,42t ha- ${ }^{-1}$ na safra 2012/13, e de 146,50 para 102,56t ha ${ }^{-1}$, na safra 2013/14, para espaçamentos entrelinhas de 0,5 e $1,1 \mathrm{~m}$, respectivamente. As menores produtividades observadas no segundo ano de estudo foram devido às condições climáticas desfavoráveis no período.

Palavras-chave: sorgo lignocelulósico, arranjo de plantas, densidade, bioenergia, manejo cultural.

\section{INTRODUCTION}

Sorghum [Sorghum bicolor (L.) Moench] presents wide genetic diversity, with cultivars improved for grain, sugar and fiber production. Thus, biomass sorghum is a promising feedstock for biofuels in all the three categories: starch-based, saccharide-based and cellulose-based. Biomass sorghum or lignocellulosic

\footnotetext{
IEmbrapa Milho e Sorgo, MG 424, Km 45, CP 285, 35701-970, Sete Lagoas, MG, Brasil. E-mail: andre.may@embrapa.br. Corresponding author.

IIUniversidade São João Del Rey (UFSJ), São João Del Rey, MG, Brasil.

IIIUniversidade Estadual do Norte Fluminense Darcy Ribeiro (UENF), Campos de Goytacazes, RJ, Brasil.

IV Petrobras Biocombustível, Rio de Janeiro, RJ, Brasil.
} 
sorghum consists of cultivars developed specifically for second generation ethanol and for electricity cogeneration. Sorghum genotypes known as biomass lignocellulosic brown mid-rib, for instance, have low lignin content, which facilitates hydrolysis of cellulose and hemicellulose for fermentation and ethanol production. Conversely, lignocellulosic non-brown mid-rib sorghum genotypes present lignin content desired in combustion, since it has a calorific value of $22-24 \mathrm{~kJ} \mathrm{~g}^{-1}$, which is 30 to $50 \%$ higher than other cell wall components (FREI, 2013).

Currently, due to unfavorable hydrological conditions, there was a reduction in the domestic supply of hydroelectricity with consequent increase in thermal generation. The Federal Government has adopted a series of incentives aiming to increase the participation of bioelectricity in the national energy mix, with the diversification and decentralization of electric power generation, and with energy bids dedicated to renewable sources, (BRAZIL, 2013). An example of this is the restructuring that has taken place in the electricity industry since 2004, which had provided the increase of cane biomass participation in this segment. According to UNICA (2013), in 2012, the surplus energy generated by the use of sugarcane bagasse in boilers exceeded 1,380MW, corresponding to approximately $2 \%$ of total Brazilian consumption. The demand extends to the replacement of petroleum and natural gas by vegetable feedstock.

One of the particularities of lignocellulosic sorghum is its sensitivity to photoperiod, which allows extending its growth cycle in over 150 days, with seeding in the spring-summer period, providing yield superior to $100 \mathrm{tha}^{-1}$ fresh weight (PARRELLA et al., 2010). Due to the speed and flexibility of its growth cycle, sorghum crops can boost the renewable thermoelectricity segment from biomass burning in sugarcane off-season.

To provide greater biomass sorghum yield, researches related to crop production system aimed to establish the ideal plant population per hectare. Thus, it is necessary to define the spacing and seeding density for commercial cultivars. In this sense, the inexistence of competition between neighboring plants provides maximum yield per plant; however, one should always aim the maximum gain per cultivated area. Converseky, there are reports citing that as intraspecific competition increases, there is an inverse relationship between the number of plants and plant yield (LOPES et al., 2005). However, this response is highly variable among cultivated species, since it is related to complex interactions between the genotype and the production environment.
Thus, the maximum yield is obtained by an optimal spatial relationship, in which the number of individuals compensates the reduction in plant yield. This relationship, in its turn, depends on the environmental conditions, due to intraspecific competition for water, nutrients and light. Furthermore, spacing and the can influence tillering and lodging of plants, which also cause changes in final plant stand.

The objective of this study was to evaluate the influence of row spacing and plant population on biomass sorghum productive performance.

\section{MATERIAL AND METHODS}

The experiments were carried out in Sete Lagoas/MG (central region of the state) for two consecutive years, with planting on September 26, 2012 (characterized by 2012/13 crop year, Year 1), and September 18, 2013 (characterized by 2013/14 crop year, Year 2). The samples were collected at 210 days after sowing and when the grain reached physiological maturity for the two studied crop years.

Trials were set in the experimental field of Embrapa Maize and Sorghum, located at $19^{\circ} 23^{\prime} \mathrm{S}$ lat., $44^{\circ} 10^{\prime} \mathrm{W}$ long., at $726 \mathrm{~m}$ asl. The climate is CWA Tropical type, with rainfall concentrated in summer, and a dry winter. The soil in the experimental area in Sete Lagoas/MG is the Oxisoil type, clayey, with approximately 60,32 and $8 \%$ of clay, silt and total sand, respectively. The area presents a record of four years fallow. Chemical analysis of the soil prior to experiment showed $\mathrm{pH}\left(\mathrm{H}_{2} \mathrm{O}\right)=6.4 ; \mathrm{P}=32.89(\mathrm{mg}$ $\left.\mathrm{dm}^{-3}\right) ; \mathrm{K}^{+}=107\left(\mathrm{mg} \mathrm{dm}{ }^{-3}\right) ; \mathrm{Ca}^{++}=4.27\left(\mathrm{cmolc} \mathrm{dm}^{-3}\right)$; $\mathrm{Mg}^{++}=0.80\left(\mathrm{cmolc} \mathrm{dm}^{-3}\right) ; \mathrm{Al}^{+++}=0.02\left(\mathrm{cmolc} \mathrm{dm}^{-3}\right)$; $\mathrm{H}^{+}+\mathrm{Al}=5.38\left(\mathrm{cmolc} \mathrm{dm}^{-3}\right) ; \mathrm{M} . \mathrm{O} .=2.7\left(\mathrm{dag} \mathrm{dm}^{-3}\right) ; \mathrm{CTC}=$ $10.7\left(\mathrm{cmolc} \mathrm{dm}^{-3}\right) ; \mathrm{V}(\%)=50.0$ e $\mathrm{m}(\%)=0.34$.

The average temperature and the accumulated rainfall during the experimental period in the crop year $1(2012-13)$ were $23.57^{\circ} \mathrm{C}$ and $746 \mathrm{~mm}$, respectively, and for crop year 2 (2013-14), $22.14^{\circ} \mathrm{C}$ and $875.4 \mathrm{~mm}$, respectively.

The experimental design was a randomized block, in factorial scheme of $4 \times 4$, with four row spacings $(0.5,0.7,0.9$ and $1.1 \mathrm{~m})$, and four plant populations $(80,000 ; 100,000 ; 120,000$ and 140,000 plants $\left.\mathrm{ha}^{-1}\right)$, with three replications. The experimental plot consisted of four $4 \mathrm{~m}$ long rows, and the two central rows were considered for evaluation, with $0.5 \mathrm{~m}$ border at the ends of each row. The experimental cultivar was CMSXS 7015, developed by Embrapa Maize and Sorghum, characterized as sensitive to photoperiod.

For soil preparation, one plowing and two harrowings were carried out before setting the 
experiments. Liming was carried out to raise the base saturation to $60 \%$, before plowing, leaving the soil to rest for three months after lime incorporation. It was applied $120 \mathrm{~kg} \mathrm{ha}^{-1}$ of nitrogen in the form of urea; $30 \mathrm{~kg} \mathrm{ha}^{-1}$ of $\mathrm{P}_{2} \mathrm{O}_{5}$ in the form of single super phosphate; and $60 \mathrm{~kg} \mathrm{ha}^{-1} \mathrm{~K}_{2} 0$ in the form of potassium chloride, according to the recommendation for forage sorghum, described by ALVAREZ et al. (1999). The recommended dose of each nutrient applied per linear meter was calculated to be distributed in each row, according to the raw spacing studied, considering the same dose of nutrients per hectare recommended for all treatments studied. For weed control, it was used, in pre-emergence, $2.5 \mathrm{~L} \mathrm{ha}^{-1}$ Atrazine herbicide. The crop was cultivated under rainfed system in the two years of study.

The spacing demarcation was carried out using an adjustable plow coupled to the hydraulic system of a tractor for each treatment. After furrows opening (4cm deep), manual sowing of sweet sorghum was carried out with the aid of a previously marked ruler indicating the spacing between plants in the row for each plant population studied. Three to four seeds were sown per ruler demarcation, and 15 days after sowing, thinning of plants was carried out in each seeding section, leaving only one plant in each section, in order to establish the optimal spacing between plants for each population studied, according to the row spacing related to each treatment.

The characteristics evaluated at harvest were: plant height (distance from the soil surface to the tip of the panicle, in meters); stem diameter (in the middle third of plants, in $\mathrm{mm}$ ); number of leaves; number of tillers per plant (data transformed by the square root of the number of tillers +1 ), fresh weight per plant (expressed in kg per plant), and total biomass per cultivated area (expressed in $\mathrm{tha}^{-1}$ ).

Analyses of individual variances were carried out for each crop year and, after detecting a low ratio between the highest and the lowest residue mean square (ratio lower than 7), considering homocedasticity of residual variances, data from the two crop years were submitted to analysis of variance by SAS (Statistical Analysis System). In case of significance in the analysis of variance, data were submitted to Tukey test at $1 \%$ probability, when there was no significant adjustment in the analyses of polynomial regression for the characteristic considered.

\section{RESULTS AND DISCUSSION}

There was no significant triple interaction between the factors of the studied characteristics.
There was double interaction between year and row spacing for number of tillers, fresh weight per plant and total biomass yield per cultivated area. In addition, there was isolated effect of year for height and number of leaves, and isolated effect of row spacing for stem diameter at $1 \%$ probability.

The average height of biomass sorghum plants was different for each year of study: 5.24 and $4.83 \mathrm{~m}$ for the 2012/13 and 2013/14 crop years, respectively. This may be due to highly variable weather conditions in each year, mainly related to water availability along the plant growth cycle. There was no precipitation from $01 / 23 / 2014$ to $03 / 01 / 2014$, totaling 37 days drought, with a maximum average temperature of $31.8^{\circ} \mathrm{C}$, which might have affected the development of biomass sorghum plants, resulting in plants $0.41 \mathrm{~m}$ shorter in the $2013 / 14$ crop year, compared to the previous crop year.

In the same way, the number of leaves also reduced in the second year of study, from 25.76 (2012/13 crop year) to 22.00 (2013/14 crop year), probably due to the reduction of plant height, as previously mentioned.

The stem diameter was influenced only by the row spacing. However, there was no variation between the mean observed for this characteristic in function of the change of row spacing, with differences of only $1.3 \mathrm{~mm}$ between the two mean extremes $(0.9 \mathrm{~m}$ and $1.1 \mathrm{~m}$ row spacing), inferring that this characteristic little interfered in fresh biomass yield, with a mean of $18.59 \mathrm{~mm}$.

The number of tillers did not change with the increase in plant population; however, it reduced with the increase of row spacing from 0.47 to 0.26 (2012/13 crop year), as emonstrated in figure 1, and from 0.54 to 0.42 tillers per plant (2013/14 crop year), for 0.5 and $1.1 \mathrm{~m}$ row spacings. The highest number of tillers in the 2013/14 crop year had been a result of the unfavorable weather conditions in the period, which had stimulated tillers appearance by the main plant. The lowest number of tillers in greater row spacing had greater competition among the crop row, since with the increase in the row spacing, there is a densification of plants in the crop row, considering a population of fixed average plants. Thus, with the highest density in the cultivation line, there is greater competition for light between plants, reducing the stimulation of tillering. According to CARVALHO et al. (2000), the light incident on grasses basis is the major environmental factor that affects the appearance of tillers in the main plant.

Fresh biomass yield was greatly influenced by row spacing, presenting a sharp reduction with the increase of row spacing for the 


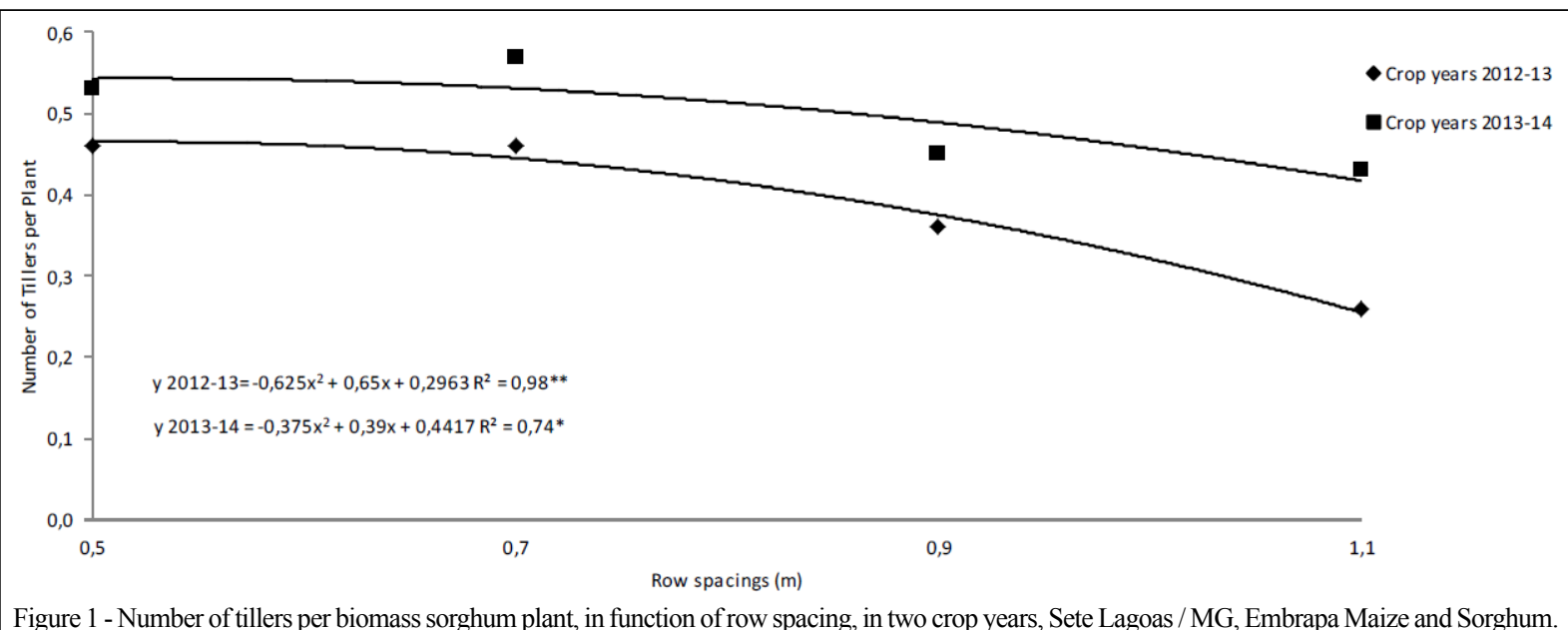

two years of study, from 146.50 to $102.56 \mathrm{tha}^{-1}$, for 0.5 and $1.1 \mathrm{~m}$ between rows, respectively, in the 2013/14 crop year (Figure 2). In the 2012/13 crop year, there was also a reduction in fresh biomass yield per cultivated area, from 180.27 to $114.42 \mathrm{t}$ $\mathrm{ha}^{-1}$, for 0.5 and $1.1 \mathrm{~m}$ between rows, respectively (Figure 2). The low yields observed in the second year of study had been due to unfavorable weather conditions in the period. The 37 days drought between January and February 2014 resulted in $0.41 \mathrm{~m}$ reduction in plant height, comparing the two years, as discussed earlier, affecting directly the biomass yield. The reduction in 3.76 leaves per plant in the 2013/14 crop year compared to the previous crop year, in function of the unfavorable weather conditions in the second year of cultivation, certainly influenced negatively the expression of biomass yield per plant.

ALBUQUERQUE et al. (2011) carried out experiments with sorghum for two years, $2006 / 07$ and $2007 / 08$, in Jaíba-MG. The authors observed that in the second year, there was a $40 \%$ reduction in biomass yield due to the lower rainfall, denoting extreme interference of climate fluctuations between the years of cultivation on sorghum yield. Under large water stress condition, in the experiment carried out in $2007 / 08$, it was noted that the increase in density led to higher losses due to higher intraspecific competition between plants in the crop rows. For each increase of one thousand plants $\mathrm{ha}^{-1}$, there was a reduction of $86 \mathrm{~kg} \mathrm{ha}^{-1}$ in dry matter.

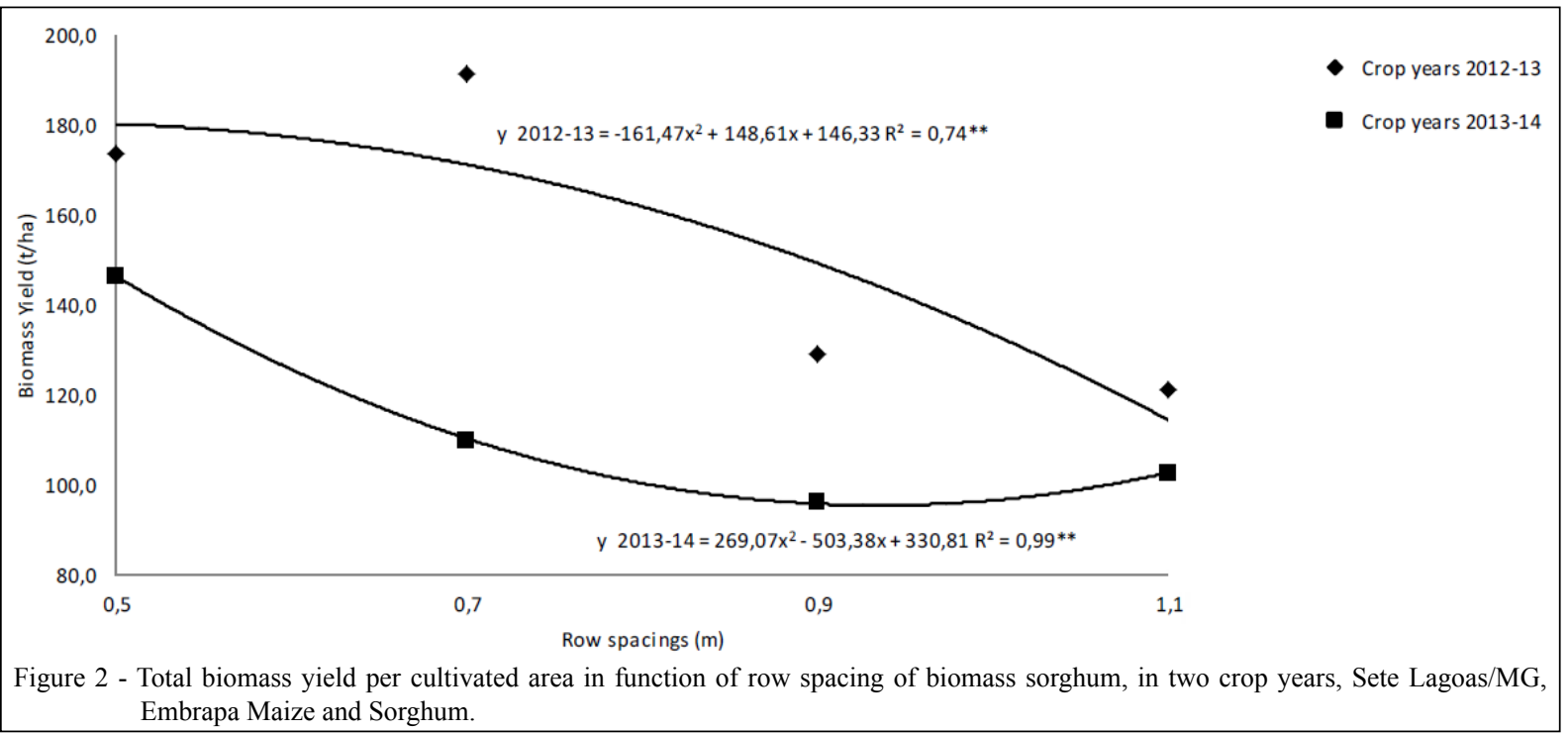

Ciência Rural, v.46, n.3, mar, 2016. 
For CMSXS 7015 biomass sorghum, the vegetative characteristics studied, this is, the number of leaves and plant height, were not affected by row spacing and plant population. However, there was a very significant yield difference for the treatments of row spacing. This response can be explained by the fresh weight per plant, which, in turn, did not show large variations between the spacing studied, only an atypical expression of row spacing of $0.7 \mathrm{~m}$ for the 2012/13 crop year, resulting in no polynomial regression adjustment for this year of study. However, the other points in the regression curve of this crop year had values of fresh weight per plant near $0.842 \mathrm{~kg}$ plant $^{-1}$. In the same way, although plant yield was lower in the second year of study (2013/14 crop year), due to the unfavorable weather conditions of the period, the means observed between the levels of row spacing were similar, around $0.705 \mathrm{~kg}$ plant $^{-1}$, with a tendency of increase in fresh weight per plant for $1.1 \mathrm{~m}$ between rows $\left(0.734 \mathrm{~kg} \mathrm{plant}^{-1}\right)$, governed by the polynomial regression $\mathrm{Y}=0,8051 \mathrm{x} 2-1.3 \mathrm{x}+1.1897, \mathrm{R}^{2}=0.87 * *$.

Thus, it was inferred that the increase in fresh biomass yield per cultivated area with a reduction in row spacing comes from the fresh weight produced by tillers, since tillering was higher in the reduced spacing (Figure 1), contributing to total biomass yield per cultivated area, and thus showing again that biomass sorghum tillering in CMSXS 7015 is a very favorable characteristic for the plant productive expression.

SNIDER et al. (2012) obtained higher yield of biomass sorghum sensitive to photoperiod in smaller row spacing $(19 \mathrm{~cm})$, and in low seeding density $\left(116,000\right.$ seeds ha- $\left.{ }^{-1}\right)$. Higher seeding rates and higher plant populations did not positively affected yield; however, according to the authors, they can promote morphological changes, such as higher plants with thinner stems, which resulted in dampingoff or plant lodging, depending on the plant structure. However, in this study of CMSXS 7015 biomass sorghum plant arrangement, it was not verified plant lodging in the treatments studied.

ALVINO et al. (2012) studied AG 2005 and Volumax forage sorghum cultivars, grown under different arrangements of plants, and found that Volumax presented dry matter yield similar between the spacings, while AG2005 showed higher yield for the $0.50 \mathrm{~m}$ spacing.

Likewise, FERNANDES et al. (2014) evaluated the effect of BRS 506 sweet sorghum plants arrangement in two crop years (normal and late seasons), when the spacing ranged from 0.5 to $0.8 \mathrm{~m}$ between rows, and plant population ranged from 80,000 to 140,000 plants $\mathrm{ha}^{-1}$, and found that the seeding in normal season resulted in higher yield of fresh weight of stems and fresh weight of total biomass per cultivated area, and $0.5 \mathrm{~m}$ row spacing resulted in higher total biomass yield in the two crop years studied.

MAY et al. (2012) studied BR 505 and CMSXS647 sweet sorghum in Patos de Minas/ MG and Sete Lagoas/MG, respectively, under different plant arrangements, and also found that the highest fresh biomass yields were observed in the $0,5 \mathrm{~m}$ row spacing, but did not find influence on yield when altering the plant population $(80,000$ to 140,000 plants ha-1).

Thus, to maximize yield per cultivated area of biomass sorghum, without significant damage to the weight yield per plant, suggested the reduction in row spacing. This increase the number of rows planted per hectare, considering that the population of plants for CMSXS 7015 cultivar did not affect the expression of the productive characteristic within the interval studied (80000140000 plants per hectare). Another studied factor was the increase in tillering in reduced spacing, which helps to increase the biomass yield per cultivated area. However, it is noted that there may be differences in the type of vegetative growth for other biomass sorghum genetic materials, indicating that for cultivars which present little tillering, the adjustment of plant population may be different, once the genetic component also influences in the tillering production rate (CARVALHO et al., 2000).

\section{CONCLUSION}

Plant population did not influence the fresh biomass yield of CMSXS 7015 biomass sorghum, due to the high tillering of the genetic material. The highest yields were obtained with $0.5 \mathrm{~m}$ row spacing.

\section{ACKNOWLEDGMENT}

The authors thank Energias Renováveis do Brasil (ERB) for financial support in the development of this research, through the Research and Development Manager, Nelson Amado.

\section{REFERENCES}

ALBUQUERQUE, C.J.B. et al. Espaçamento e densidade de semeadura para cultivares de sorgo granífero no semiárido. Bragantia, v.70, n.2, p.278-285, 2011

ALVAREZ, V.V.H. et al. Interpretação dos resultados das análises de solos. In: RIBEIRO, A.C. et al. (Ed.). Recomendações para

Ciência Rural, v.46, n.3, mar, 2016. 
o uso de corretivos e fertilizantes em Minas Gerais $-5^{\text {a }}$ apr. Viçosa: Comissão de Fertilidade do Solo do Estado de Minas Gerais, 1999. p.25-32.

ALVINO, F.C.G. et al. Rendimento de fitomassa do sorgo sacarino sob sistemas de captação de água "in situ". Agropecuária Científica no Semi-Árido, v.8, p.54-59, 2012.

BRASIL. Ministério de Minas e Energia. Empresa de Pesquisa Energética. Plano decenal de expansão de energia 2022. Brasília, 2013. 410 p.

CARVALHO, C.A.B. de et al. Demografia do perfilhamento e taxas de acúmulo de matéria seca em capim 'tifton 85 ' sob pastejo. Scientia Agricola, v.57, n.4, p.591-600, 2000.

FERNANDES, P. G. et al. Influência do espaçamento e da população de plantas de sorgo sacarino em diferentes épocas semeadura. Ciência Rural, v.44, n.6, p.975-981, 2014.

FREI, M. Lignin: characterization of a multifaceted crop component. Scientic World Journal, v.2013, p.1-25, 2013.
LOPES, S.J. et al. Tamanho de parcela para produtividade de grãos de sorgo granífero em diferentes densidades de plantas. Pesquisa Agropecuária Brasileira, v.40, n.6, p.525-530, 2005.

MAY, A. et al. Variedades de sorgo sacarino em diferentes espaçamentos e população de plantas. Revista Brasileira de Milho e Sorgo, v.11, p.278-290, 2012.

PARRELLA, R.A.C. et al. Desenvolvimento de híbridos de sorgo sensíveis ao fotoperíodo visando alta produtividade de biomassa. Sete Lagoas: Embrapa Milho e Sorgo, 2010. 25p. (Embrapa Milho e Sorgo. Boletim de Pesquisa e Desenvolvimento, 28)

SNEIDER, J.L. et al. The effect of row spacing and seeding rate on biomass production and plant stand characteristics of non-irrigated photoperiod-sensitive sorghum (Sorghum bicolor (L.) Moench). Industrial Crops and Products, v.37, p.527-535, 2012.

UNICA (UNIÃO DA INDÚSTRIA DA CANA-DEAÇÚCAR). Available from: <http://www.unica.com.br/>. Accessed: May 11, 2013. 